\title{
AuXILIARY ANd Aspectualizer Verbs: Some Syntactic And Semantic Distinctions
}

\author{
Verbos auxiliares e aspectualizadores: algumas \\ distinções sintáticas e semânticas
}

\author{
Teresa Cristina Wachowicz*
}

\section{INTRODUCTION}

The present work was motivated by the preliminary results of a research project coordinated by me, in progress at the Federal University of Parana. Our objective is to analyze the relationship between lexicon and sentence phenomena and their implications in the aspectual readings of Brazilian Portuguese (BP) sentences.

One of the sub-themes of the project concerns the verbal periphrases and the role performed by the constituent verbs. The readings of periphrases such as those presented in sentences (1) to (6) immediately raise the following questions: What is the difference between verbs estar/ter 'be/ have', which seem to have a smaller semantic load, and começar/acabar 'start/ finish', which are lexically more loaded? What role verbs like ficar 'stay' and continuar 'continue' play?

(1) Maria está sabendo Física/cozinhando a janta/clicando no site. 'Mary is ? knowing Physics/ cooking the dinner/ clicking the site'.

(2) Maria tem ? sabido Física/ OK cozinhado a janta/ OK clicado no site.

'Mary has been? knowing Physics/ cooking the dinner/ clicking the site'.

(3) Maria começou ? a saber Física/ OK a cozinhar a janta/ OK a clicar no site.

'Mary started? knowing Physics/ cooking the dinner/ clicking the site'. 
(4) Maria acabou de ? saber física/ OK cozinhar a janta/ OK clicar no site.

'Mary finished? knowing physics/ cooking the dinner/ clicking the site'.

(5) Maria continua sabendo Física/cozinhando a janta/clicando no site.

'Mary continues to? know Physics/ cook the dinner/ click the site'.

(6) Maria fica sabendo Física/cozinhando a janta/clicando no site. 'Mary keeps ? knowing Physics/ cooking the dinner/ clicking the site'.

The terminology found in the literature of the area does not offer much uniformity and agreement.

The aim of the present work is to present some diachronic, syntactic and semantic criteria for the distinction between these two assumed verbal categories. The central hypotheses are the following: 1) auxiliary verbs are undergoing a grammaticalization process in BP periphrases, but aspectualizers are not; 2) auxiliary verbs lose transitivity and thematic attribution, keeping the actionality features through semantic persistence, whereas aspectualizers - specially the ones of punctual actionality - do not lose transitivity, and the thematic attribution is maintained by a direct complement with eventive denotation or time interval; 3) in a theoretical perspective, auxiliaries denoted eventuality, and the relationship between the intervals corresponding to the two verbs in the periphrase is one of inclusion. The ascpectualizers, on the other hand, denote operators on eventualities, which, on its turn, are denoted by the direct complement; and the relation here is one of restriction.

In section 1, I introduce some approaches offered by theories of different tendencies: In section 2, based on some clues provided by the theories, I propose some tests to distinguish auxiliaries and aspectualizers. Finally, in section 3, I present some theoretical conclusions and possible applications in specific behaviors of these verbs.

\section{1.o Terminology And Approaches Found In The Literature.}

The works are characterized by a lack of general agreement. However, some observations can be very interesting, mainly if one's aim is to associate syntactic-semantic criteria to diachronic ones.

Initially, in the diachronic perspective, 1) Câmara Jr (1979, p. 163170 ) argues that the BP verbal periphrases are formed by an auxiliary verb, which has a mere grammatical meaning (categories of number, person, tense and mood) and a second main verb in the infinitive, gerund, or participle 
forms. However, such composition brings about a number of aspectual interpretations: the permansive aspect (in ter 'have' + participle periphrases), the static duration aspect (in estar 'be' + gerund periphrases), the dynamic duration aspect (in ir 'go', vir 'come', and andar 'walk' + gerund periphrases), the terminative aspect (acabar 'finish' + gerund or infinitive), and finally the inceptive aspect (começar 'start' + inifinitive).

2) Mattos-e-Silva (1989, p. 437-471), through an analysis of a corpus of ancient Portuguese - from the XIII ${ }^{\text {th }}$ century to the XIV ${ }^{\text {th }}$ century follows the terminology found in Câmara Jr (1979) and adds some syntactic conclusions. The auxiliary in ter /haver 'have' + participle always carries a transitive feature, and the participle maintains its agreement with the direct object (7). Structures with andar 'go', seer 'be', jazer 'remain', estar 'stay', and ir 'go' + gerund quantitatively exhibit a more bi-sentencial behavior, for the first verb still keeps the strong semantic load of a full verb. In other words, the phenomenon does not allow periphrasis structures with auxiliary (8) to be mastered:

(7) Aquelas cousas que ten aparelhadas.

'Those things that [you] have prepared'.

(8) E, estando (ele) a hua feestra rogando Nosso Senhor e louvandoo mui de coraçon, viu hua luz viir...

'And, being (him) at a window praying for Our Lord and praising him with all his heart, he saw a light come...'

As for the other verbs that interest us, such as verbs começar 'start', ficar 'stay', continuar 'continue', they could not be found in the analyzed corpus.

3) Squartini (1998, p. 1-34), in an extensive work about aspect and actionality in periphrases of romance languages, proposes a diachronic analysis, based on the notion of grammaticalization. Recalling Hooper 1991, the author considers that grammaticalization is an unidirectional historical process, which follows the lexicon $>$ syntax $>$ morphology path. Auxiliary verbs are undergoing a grammaticalization process and exhibit what he calls 'desemantization', or the loss of semantic features. But what is more interesting for us is the idea that, despites this, auxiliary verbs maintain some feature, what is called 'semantic persistence'. In this sense, verbs such as começar 'start' and acabar 'finish' undergo desematization. The auxiliary verb productivity in a language depends on the feature that persists.

4) Perini (1989, p. 228-239) associates the categorization of the auxiliary verb to the passive voice. Periphrases containing auxiliaries move in block in the transformation to the passive (9), whereas other phrases do not accept the passive (10): 
(9) João tem pintado casas no centro 'John has been painting houses in the city center'.

$\Rightarrow$ Casas no centro têm sido pintadas pelo João.

'Houses in the city center have been painted by John'.

(10) João mandou pintar casas no centro. 'John ordered to paint houses in the city center'.

$\Rightarrow$ ? Casas no centro foram mandadas ser pintadas por João. 'Houses in the city center were ordered to be painted by John'.

5) Castilho (2003, p. 90-94), with more descriptive aims, says that the auxiliary contributes to the compositional reading of aspect. But for accessing an auxiliary verb, there are specific tests, mainly those of syntactic nature: a) the different subjects test (11); b) the scope of negation test (12); c) the test of semantic alterations of V1 with the insertion of locatives (13).

(11) a. João mandou seu irmão entrar. (mandar is not an auxiliary verb) 'John ordered his brother to come in'.

b. ? O aluno tinha seu irmão saído. (ter is an auxiliary verb) 'The student had his bother left'.

(12) a. Ele acabou não comprometendo a mulher. (acabar is not an auxiliary verb) 'He ended up not implicating his wife'.

b.? Eles estão não comprometendo a mulher. (estar is an auxiliary verb) 'They are not implicating their wives'.

(13) a. José começou aqui em Curitiba a nadar em piscina fria. (começar has a continuing meaning) Joseph began here in Curitiba to swim in a cold-water swimming-pool'.

b. José está na janela parado olhando o desfile passar. (estar recovers its sense as a full verb) Joseph is standing at the window watching the parade pass by'.

What seems more interesting for us here is the third test, which suggests the heterogeneous behavior of the auxiliary verbs. In other words, in some contexts - especially with locatives - they recover the sense of full verbs. Thus, the auxiliary verbs are under the process of grammaticalization, which may exhibit different stages in one and the same synchronic cut, whereas the same does not occur with aspectualizers.

6) Neves $(2000$, p. 25-65), with a promising aim of a grammar of usage for Brazilian Portuguese, classifies verbs based on mainly semantic criteria. In this sense, there are verbs that predicate (batucar 'drum', 
cumprimentar 'greet', permanecer 'remain'), and that are different from the verbs that do not predicate: modalizers (dever 'must', poder 'can', precisar 'need'), aspectual verbs (passar ' pass', começar ' start', acabar 'finish', viver 'live', ir 'go' + gerund; estar 'be' + gerund) and auxiliaries (ter, haver 'have' + participle, ir 'go' + infinitive; ser 'be' + participle).

In the present work, the auxiliary verbs decrease in number, and are restricted to verbs ter, haver 'have', ir 'go' and ser 'be', whereas verbs such as estar 'be', classically considered as auxiliary verbs, here are assigned to the category of aspectual verbs. But the question is the following: Auxiliary verbs, then, would not have aspect? Our answer is yes, and, according to Squatini 1998, it is the persistent aspectual feature of the auxiliary verb that contributes to its productivity in a language.

Having more theoretical aims in mind, 7) Verkuyl (1999, p. 82-92) distinguishes aspectualizer verbs from auxiliary verbs by the fact they promote a restriction in the sentence predication: begin, stop, finish, complete, keep, and continue are verbs that operate over a time interval denoted by the main verb. Moreover, aspectualizers of punctual value (begin, stop, finish, complete) will be verbs that 'decrease' the size of such interval (14). In addition, aspectualizers do not necessarily need to be in periphrases in order to promote such restriction: John began a book (example from PUSTEJOVSKY,1996).

\section{CONCLUSION:}

In a general analysis of the works studied, auxiliary verbs are full verbs rather, which lose some lexical semantic load and undergo grammaticalization in periphrases. Aspectualizer verbs are verbs that rather denote operation over other eventualities and that are not undergoing grammaticalization.

\subsection{SYNTACTIC-SEMANTIC VARIATION}

In order that we can reach an interesting generalization about the difference between auxiliaries and aspectualizers, some tests point at interesting paths:

1) In sentences accepted in present-day Brazilian Portuguese, verbs ter 'have' and estar 'be' sometimes behave like a full verb (15), other times like an auxiliary verb (16):

(15) João tem a casa pintada. 'John has the house painted'

(16) João tem pintado a casa todos os anos. 'John has painted his house every year' 
2) In sentences accepted in present-day Brazilian Portuguese, verbs estar 'be' (17) and vir 'come' (18) with locatives recover their full meaning:

(17) As crianças estão sempre em volta me pedindo pra contar historinhas. (VARSUL/PR)

'The children are always around asking me to tell them stories'. (VARSUL/PR)

(18) Muitas pessoas vêm pra cá tentando abrir postos. (VARSUL/PR) 'Many people come here to try to open petrol stations'. (VARSUL/ PR)

3) All auxiliary and aspectualizer verbs maintain their occurrences as full verbs in mono-sentencial structures, but aspectualizer verbs exhibit causative alternation:

(19) João tem muitos amigos./ * Muitos amigos tem com o João. 'John has many friends'. / 'Many friends have with John'.

(20) O compositor está no palco./ * No palco está com o compositor. 'The composer in on the stage'./ * 'On the stage is with the composer'.

(21) João começou o livro./ OK O livro começou com o João. 'John started the book'./ OK 'The book started with John'.

(22) O professor acabou a aula./ OK A aula acabou com o professor. 'The teacher finished the class/ OK The class finished with the teacher'.

4) Auxiliary verbs ((23) and (24)) have lost their transitivity (PERINI,1989). Questions that can retrieve the auxiliary verbs complement are not possible, even if it is circumstantial. In what concerns aspectualizers ((25) and (26)), the question that retrieves transitivity is possible:

(23) Maria está pensando nisso.

'Mary is thinking about this'.

? Onde Maria está?/ OK Em que Maria pensa?

'?Where is Mary?'/ OK 'About what Mary thinks?'

(24) João tem pintado casas.

'John has painted houses'.

? O que João tem/ OK O que João pinta?

'?What has John'/ OK What does John paint?'

(25) João começou a pintar casas.

'John started to paint houses.'

OK O que João começou?/ OK O que João pinta? 
OK 'What did John start?'/ OK What does John paint?'

(26) Maria acabou de escrever o livro. 'Mary has finished writing her book'.

OK O que Maria acabou?/ OK O que Maria escreve? OK 'What has Mary finished?'/ OK 'What does Mary write?'

5) The auxiliary verbs lose their thematic attribution, and the thematic function of the main verb is evidenced through the paraphrase "what someone does is..." (CANÇADO, 2002) ((27) and (28)). In the case of the aspectualizer verbs, the thematic attribution is done through the direct complement ((29) and (30)):

(27) Maria está pensando nisso. 'Mary is thinking about this'.

o que Maria faz é pensar nisso.

'What Mary does is to think about this'.

(28) João tem pintado casas.

'John has painted houses'.

O que João faz é pintar casas.

'What John does is to paint houses'.

(29) João começou a pintar casas.

'John started to paint houses'.

o que João faz é pintar casas.

'What John does is to paint houses'.

(30) Maria acabou de escrever o livro.

'Mary has finished writing her book'.

o que Maria fez foi escrever o livro.

'What Mary did was to write her book'.

6) The periphrases with auxiliary verbs have less acceptance of negation in the middle of the periphrasis ((30) and (31)) (CASTILHO, 2003)):

(31) ? João tem não comprado livros. ?'John not has bought books'.

(32) ? Maria está não concorrendo ao prêmio. ?'Mary not is running for the prize'.

(33) João acabou não comprando o livro. 'John finished/ended up not buying the book'.

(34) Maria começou não aceitando o prêmio. 'Mary started not accepting the prize'.

In order to characterize these verbs, we propose the addition of semantic properties to the synthesis of the syntactic, descriptive, and historical criteria of the approached theories. Thus, auxiliary verbs: a) denote stative 
eventualities and undergo grammaticalization; b) they keep their actionality features by semantic persistence (see Bertinetto's table below); c) they lose transitivity and thematic attribution; d) they denote durative time intervals within which the interval(s) of the main verb are included (WACHOWICZ, 2005). In this sense, verb estar 'be', in a periphrasis like João está estudando 'John is studying', has the semantic role of opening a durative time interval in the present within which the interval - episodic or iterative - denoted by the gerund estudando 'studying' is included. In João tem pintado casas 'John has painted houses', the same phenomenon occurs: verb ter 'have' opens a time interval within which smaller time intervals are necessarily added by the participle pintado 'painted'.

On the other hand, aspectualizer verbs: a) do not denote eventualities, not even the punctual ones (achievements) (VENDLER, 1967; DOWTY, 1979), and are not undergoing grammaticlaization; b) they do not lose transitivity and select eventive or temporal complements; c) they denote operators over the events denoted by the direct complement, as interval restrictors (VERKUYL, 1999). Thus, in João acabou de cozinhar a janta 'John has just finished cooking dinner', the verb acabou de 'finish' selects the event cozinhar a janta 'cooking dinner' and restricts the denotation towards the end ${ }^{1}$, as in João começou a cozinhar a janta 'John started cooking dinner', verb começar a 'start' selects the event cozinhar a janta 'cook dinner' and restricts the denotation towards the beginning.

\begin{tabular}{|l|c|c|c|}
\hline & durative & dynamic & Homogeneous \\
\hline States & + & - & + \\
\hline Activities & + & + & + \\
\hline Achievements & - & + & - \\
\hline Accomplishments & + & + & - \\
\hline
\end{tabular}

Table of feature subspecialization of vendlerian verb classes - in Bertinetto (2001)

\section{REMARKS}

Some observations might be interesting, if we recall some comments found in other texts dealing with the subject:

1) Cardoso and Pereira (2003), for instance, distinguish aspectual auxiliary verbs (35) from temporal auxiliary verbs (36):

(35) Maria tem escrito muitos livros. 'Mary has written many books'.

(36) Maria tinha escrito muitos livros. 'Mary had written many books'.

1 If the main verb is an achievement, the verb acabou de 'finish' restricts the denotation towards the beginning of a state (in an inchoative reading): João acabou de entrar no banho 'John has just finished enter in the shower'. So, in other words, these readings also depend on the actionality of the main verb. 
If we recall the hypotheses presented previously, we can justify those distinctions in the following terms: both aspectual auxiliary verbs and temporal auxiliary verbs keep their semantic feature of durativity, but the aspectual auxiliary verbs hold a relation of inclusion between the intervals denoted by the reference time (of the auxiliary verb) and the event time (of the main verb), and the temporal auxiliary verbs have a posteriority/anteriority relation between the denoted intervals of reference time (again, that of the auxiliary verb) and the event time (that of the main verb) (JOHNSON,1981; BERTINETTO, 1982).

Other data that call our attention are those presented by 2) Pustejovsky (1996), and recovered by Verkuyl (1999), that concern the occurrences of aspectualizer verbs in simple sentences (37), which present ambiguity ((38) and (39)) and seem to maintain the denotation of operators over eventualities. But the question is: In (37), where is the eventuality over which the aspectualizer operates? If the aspectualizer verbs select events (37) or time intervals (40) as direct complements, this could be included in the complement's lexical information. A sufficiently robust lexical theory can give us some answers. The structure qualia, from Pustejovsky (1996), for instance - in information about the TELLIC and AGENTIVE roles - has an eventive denotation: In the TELLIC role, there is the event of reading, and in the AGENTIVE role, there is the event of writing. This can explain the ambiguity of (38) and (39). The aspectualizer verb, in this sense, has to find an eventuality over which to operate. It may be found in the lexicon:

(37) João começou o livro. 'John started the book'.

(38) João começou a ler o livro. 'John started reading the book'.

(39) João começou a escrever o livro. 'John started writing the book'

(40) João começou o dia lendo o livro. 'John started his day reading the book'

\section{CONCLUSION}

Despites the fact there is a lexical distinction between what is considered an auxiliary verb and what is considered an aspectualizer, the conjunctist theoretical approach could unify the concepts from the starting point of saying that the eventualities or operators denoted by the verbs of the verbal periphrases or phrases are in permanent interaction. The type of relation depends on the lexical and flexional information of the verbs. Differentiation or unification? This would be a beautiful theoretical discussion.

On the other hand, empirically speaking there is a series of other 
specific examples that would need to be analyzed more carefully, such as the periphrases acabou lendo 'ended up reading', chegou a cantar 'came to sing' which have visible pragmatic implications. The role of prepositions in these readings also needs a deeper analysis. As any object of linguistic study, the investigation of verbal periphrases and the role of the auxiliary and aspectualizers verbs seems endless...

\title{
RESUMO
}

Este trabalho tem o objetivo de distinguir o comportamento de verbos auxiliares e aspectualizadores no português brasileiro. Alguns verbos prototípicos são estar, continuar, ficar, ter (auxiliares) and começar, acabar, parar (aspectualizadores). Assumo aqui que há traços semânticos em interação com estruturas sintáticas que se modificam pelo processo histórico. Na perspectiva semântica, auxiliares perdem traços lexicais informação temática e aspectual -, mas parecem preservar traços accionais, especialmente o durativo. Este fenômeno é chamado na literatura de "persistência semântica" e caracteriza a desemantização das perífrases com auxiliar. Por outro lado, verbos aspectualizadores não perdem traços semânticos, pois verbos como começar and parar não exibem comportamento de desemantização e mantêm seu valor original. Na perspectiva sintática, os auxiliares perdem transitividade e não necessitam de complemento para encerrar significado. Verbos aspectualizadores necessitam de complemento que denote eventos temporalizados ou intervalos de tempo, e podem em algumas estruturas ser elididos ou nominalizados. Assim, na perspectiva histórica, os auxiliares estão em processo de gramaticalização, mas os aspectualizadores não. Auxiliares eram predicados que denotavam eventualidades cujo traço durativo se mantém, e os aspectualizadores não são predicados e denotam operadores sobre evento, denotado pelo complemento direto.

Palavras-chave: Verbo Auxiliary; Verbo Aspectualizador; Perifrase.

\begin{abstract}
The present work aims at distinguish auxiliaries and aspectualizers verbs behavior in Brazilian Portuguese. Some prototypical verbs of these kinds are estar, continuar, ficar, ter (auxiliars) and começar, acabar, parar (aspectualizers). I assume that there are semantic features in interaction with syntactic structures that are directly modified by historical
\end{abstract}


processes. In semantic perspective, the auxiliaries lost some lexical features - aspect and thematic information, but seem to preserve actionality features, specially the 'durative' one. This phenomenon is called in the literature "semantic persistency" and characterizes the desemantization of auxiliaries in periphrases. On the other hand, aspectualizer verbs do not lose semantic features, because verbs such as begin 'começar' and stop 'parar' do not fulfil the requirement of desemantization and maintain their original value. In syntactic perspective, the auxiliaries lose transitivity and do not need a direct complement to enclose a meaning. Aspectualizers verbs need a complement that denotes temporalized events or time intervals, but they can be in some structures elllipsed or nominalized. So, in historical perspective, auxiliaries are in grammaticalization process, but aspectualizers do not. Auxiliaries were predicates and denoted eventualities which actually maintain the durative feature, and the aspectualizers aren't predicates and denote operators that must act on another event, which is its direct complement.

Keywords: Auxiliar Verb; Aspectualizer Verb; Periphrasis.

\section{REFERENCES}

BERTINETTO, Pier Marco. Intrinsic and extrinsic temporal reference. On restricting the notion of 'reference time'. Journal of Italian Linguistics. p. 71-108, 1982.

On a frequent misunderstanding in the temporal-aspectual domain: the 'perfectivetelic confusion. In: CECHETTO, C. et al. Semantic Interfaces: reference, anaphora and aspect. Stanford: CSLI Publications, 2001. p. 177-210.

CAMARA Jr., Joaquim Mattoso. História e estrutura da língua portuguesa. 3. ed. Rio de Janeiro: Padrão, 1979.

CANÇADO, Márcia. Posições argumentais e propriedades semânticas, 2002. (mimeo)

CARDoso, Adriana; PEREIRA, Susana. Contributos para o estudo da emergência do tempo composto em português. Brasília: Revista da Abralin, n. 2, v. II, p. 159-181, 2003.

CASTILHO, Ataliba T. de. O aspecto verbal no português falado. Gramática do Português Falado. Campinas: Ed. da Unicamp, v. 7, p. 83-121, 2003.

DOWTY, D. Word Meaning and Montague Grammar. Dordrecht: Kluwer, 1979.

HOOPER, Paul J. On some principles of grammaticalization. In: TRAUGOTT, E. C.; HEINE, B. (Eds.). Approaches to grammaticalization. Ámsterdam, Philadelphia: Benjamins, 1991. p. $17-35$.

JOHNSON, Marion R. A unified temporal theory of tense and aspect. TEDESCHI, P. J.; ZAENEN, A. (Ed.). Syntax and Semantics. New York: Academic Press, Inc, v. 14. p. 145$175,1981$.

MATTOS-e-SILVA, Rosa Virgínia. Estruturas trecentistas: elementos para uma gramática do português arcaico. Lisboa: Imprensa Nacional, 1989.

NEVES, Maria Helena de Moura. Gramática de usos do português. São Paulo: Ed. Unesp, 
Wachowicz, T. C. Auxiliary And Aspectualizer Verbs: Some Syntactic And Semantic Distinctions

2000.

PERINI, Mário A. Sintaxe portuguesa: metodologia e funções. São Paulo: Ática, 1989.

PUSTEJOVSKY, James. The generative lexicon. Cambridge, MA: MIT Press, 1996.

SQUARTINI, Mario. Verbal periphrases in Romance. Berlin, New York: Gruyter, 1998.

VENDLER, Zeno. Linguistics in Philosophy. Ithaca, NY: Cornell, 1967.

VERKUYL, Henk J. Aspectual issues: studies on time and quantity. Stanford: CSLI Publications, 1999.

WACHOWICZ, Teresa Cristina. O aspecto do auxiliar. In: GT 'Teoria da Gramática', da ANPOLL, 2005. Ouro Preto-MG: UFMG.

Submetido em: 17/03/2007.

Aceito em: 25/09/2007. 